\title{
Characteristics and Retrofit Constraints of Grayfield in Korean Cities
}

\author{
Jun-Won Seo ${ }^{1}$ and Joo-Lim Lee ${ }^{2, *}$ \\ 1 California State University LA, 801 South Grand Ave, Los Angeles, CA 90017, USA; junwon1977@gmail.com \\ 2 The Principal of URI Urban Institute Co., Ltd., 10, Wangsimni-ro 21da-gil, Seongdong-gu, Seoul 04714, Korea \\ * Correspondence: leejoolim@gmail.com; Tel.: +82-2222-04617
}

Received: 4 March 2019; Accepted: 16 April 2019; Published: 22 April 2019

\begin{abstract}
The purpose of this study is to analyze the characteristics and the retrofit constraints of grayfield in Korea and to suggest ways to revitalize them. To do this, we firstly classify grayfields according to the variables of development level and site location through factor and cluster analysis. Secondly, we found that strong improvement and land use change are the factors to vitalize grayfields through an independent $t$-test. Thirdly, we analyze the factors that affect the revitalized project in order to derive the retrofit constraints. As a result of the analysis, we suggest that the government take steps to lift regulations to encourage complex development, provide administrative and fiscal support for demolition costs, and deal with ownership-related issues. The government also needs to monitor the private sector's stable operation and request private sector's support for the local community and a public transport-oriented development method for the revitalization of the site as well as carbon reduction.
\end{abstract}

Keywords: grayfield; retrofit constraint; revitalization of the city; urban regeneration; urban retrofit

\section{Introduction}

\section{Research Background and Objectives}

Sustainable development to conserve resource and protect the environment can be achieved through the efficient use and redevelopment of the city. The revitalization of deteriorated areas in the city is receiving a great deal of attention, and the retrofit of large-scale underutilized premises plays the role of catalyst for urban regeneration.

There are many revitalization cases for underutilized premises such as blighted buildings, abandoned factories, shopping malls, and stations in the United States and European countries. Notably, the redevelopment of grayfield, nonindustrial abandoned premises has emerged as an infill development area after the redevelopment of brownfield (a former industrial site) since the 2000s. The former abandoned commercial site due to its aging and change in shopping trends can now become a new premise which leads to regenerate community and reduce carbon emissions by mixed-use and transit-oriented development (TOD).

In Korea, which is located in Asia, underutilized premises in urban areas have not become a notable issue because there has been a consistent demand for urban development due to high population and economic growth. However, as population and economic growth in Korea recently slowed, large-scale greenfield development is no longer necessary, and demand for new accommodating spaces becomes major urban planning issues in Korea. In this situation, brownfields due to factory relocation have redeveloped since the 1990s, and the interest in the grayfield, nonindustrial abandoned premises is increasing after completion of redevelopment in large-scale brownfields. Therefore, analyzing the 
characteristics and development factors for grayfield in Korea can be a necessary step for sustainable development in Korea.

Therefore, we analyze the characteristics by location and development of existing premises, the activation and restriction factors of revitalization. Also, we discuss the potential of grayfield retrofit and the roles of government for the revitalization of both grayfield and its community.

\section{Theoretical Study and Literature Review}

\subsection{The Definition and Category of Grayfield}

A relatively new term in the planning field, 'Grayfield' is a term used here to describe occupied but economically and technologically obsolescent. Unlike brownfields, however, there is usually no need for site remediation [1]. Grayfield has been mentioned in many studies, and its common characteristics are economically obsolete or underutilized premises, outdated and blighted architecture, considerable site, surrounding buildings, lacking reinvestment capital, need for intervention by public and private entities, and environmentally uncontaminated [1-5]. Therefore, we define grayfields in this study as "occupied but economically obsolescent nonindustrial premises with the considerable site and need the intervention of public or private entities."

The term 'grayfield' is coined as a description of the large asphalt parking lots associated with large commercial sites. However, grayfield is a site that can include variable facilities. The Congress for New Urbanism (CNU) [1] states that grayfield includes abandoned not only shopping malls and department stores but also underused airports and areas formerly occupied by military bases. Hadjimichael [6] mentioned some abandoned additional fields in the perspective of infill development: orange fields (the land which accommodate not so efficient functions), grayfields (pedestrian paths, squares, abandoned train lines/roads, and parking lots), government/municipal fields (land run by central or local authorities), and underground fields (underground space such as road tunnels, parking places, and electricity stations). The Ministry of Land, Infrastructure, Transport, and Tourism (MLIT) in Japan [7] uses the term 'Idle Assets' (unused building) as a concept similar to grayfield; however, it also includes small buildings.

There is no research on grayfield in Korea (Previously, researchers in Korea studied brownfields as abandoned sites [8-11].), but a few pieces of research on concepts similar to grayfield exist. Kim, J. and Yu, K. [12,13] researched 'Unfinished Building' (abandoned building because construction was suspended), which includes commercial building, hospital, apartment complex, residential building, accommodation, factory, and education facilities. Such facilities, except factory and apartment complex (Because grayfield means an economically obsolescent and environmentally uncontaminated premises, it excludes a factory and housing.), can be included in grayfield if the premises are abandoned even after construction completion. The Evaluation Team of Pre-Negotiation System for Urban Planning Change (PNSUPC) and Joo, M. [14,15] analyzed 'Pre-Negotiable Site' (It is similar to orange fields stated by Hadjimichael [6].), the site which needs the abolishment or change of planning regulation to encourage development. Among them are a bus terminal, train station, warehouse, wholesale market, and unused school ground. These facilities except factory can also be included in grayfields. Ministry of Economy and Finance [16] researched 'Old government site'. As a result, the grayfield category by the facility can be as follows (See Table 1). 
Table 1. The Category of Grayfields ${ }^{1}$.

\begin{tabular}{|c|c|c|}
\hline Category & Facility & Other Terms in the Previous Studies \\
\hline \multirow{7}{*}{ Commercial Building } & Shopping Mall & $\begin{array}{c}\text { Grayfield [1], Idle Asset [7], Unfinished } \\
\text { Building [12,13] }\end{array}$ \\
\hline & Department Store & $\begin{array}{c}\text { Grayfield [1], Idle Asset [7], Unfinished } \\
\text { Building [12,13] }\end{array}$ \\
\hline & Wholesale Mart & Notable grayfield [1], Idle Asset [7] \\
\hline & Retail Building & Idle Asset [7], Unfinished Building [12,13] \\
\hline & Underground Arcade & Underground field [6] \\
\hline & Wholesale Market & Pre-Negotiable Site $[14,15]$ \\
\hline & Warehouse & Orange field [6], Pre-Negotiable Site $[14,15]$ \\
\hline \multirow{3}{*}{ Accommodation } & Hotel & Idle Asset [7], Unfinished Building [12,13] \\
\hline & Resort Hotel & Idle Asset [7], Unfinished Building [12,13] \\
\hline & General Hospital & Idle Asset [7], Unfinished Building $[12,13]$ \\
\hline \multirow{4}{*}{ Transportation Facility } & Bus Terminal & Orange field [6], Pre-Negotiable Site $[14,15]$ \\
\hline & Train station & Orange field [6], Pre-Negotiable Site $[14,15]$ \\
\hline & Airport & Grayfield [1] \\
\hline & Parking Lot & Grayfield [6] \\
\hline \multirow{4}{*}{ Public Facility } & Public offices & $\begin{array}{l}\text { Government/municipal field [6], Old } \\
\text { government site [16] }\end{array}$ \\
\hline & School & Orange field [6], Pre-Negotiable Site $[12,13]$ \\
\hline & Stadium & Orange field [6] \\
\hline & Military Base & Grayfield [1] \\
\hline
\end{tabular}

${ }^{1}$ All facilities must be abandoned or underutilized premises with a considerable site in the city.

\subsection{The Cause of Emerging Grayfield and the Constraints of Retrofit}

Grayfields have emerged as a result of urban expansion, the slowdown of population growth, and changes in user trends. The spread of suburbanization or greenfield development has weakened not only old downtowns, but also old residential areas in suburbs because growth inducers, which include shopping malls [3,4], government/municipal offices, private offices, and sometimes prestigious schools moved into new development areas. In Korea, central and local governments have developed new towns or new districts on outskirts to accommodate a growing population, and the development has led to the deterioration of old urban areas next to government offices and prestigious schools that have been moved. The slowdown in both population and economic growth of the city has divided the urban area into a growing district and a declining district [3,17]. In Korea, such slowdown has shown the problem of declining commercial areas, abandoned retail buildings, and department stores in older urban areas, in contrast to the popularity of new suburban shopping malls (power centers) and warehouse store on the outskirts or the suburban.

Moreover, the changes in user trends have weakened the competitiveness of old facilities, that made them deteriorate economically [3,17-19]. There have been 'deal mall' problems in the United States and Japan. (Congress for New Urbanism, Price Waterhouse Coopers CNU, and PwC, which conducted an investigation into the status of grayfields in the United States, and found that $7 \%$ of shopping malls are grayfield sites and that within the next five years another $12 \%$ of shopping malls will become such sites [19].) The breakaway of major tenants, such as department stores and wholesale marts, from shopping malls due to the growth of online shopping is expected to lead to an increase of grayfield sites. From 2007 to 2017, 638 department stores and 791 wholesale marts are closed in the United States [20]. (On the other hand, Amazon's revenues in the US grew from $\$ 15 \mathrm{bn}$ to $\$ 178 \mathrm{bn}$, or by $\sim 1000 \%$, from 2007 to 2017 (CAGR: 28.2\%) [21].) Sears Holdings closed 1635 of 2205 stores, leaving only 570 stores in the US [22], and Macy's announced in August 2016 that it would close around 100 of its 728 stores due to worsening profitability and to raise on investment efficiency. Macy's had completed more than 80 stores of its 100 planned stores closures in early 2018 [23]. According to the Japan Council of 
Shopping Centers (JCSC) [24], the number of the shopping mall (shopping center) has decreased from 88 in 2008 to 48 in 2017. According to the Japan Department Store Association (JDSA) [25], there are 217 stores in February 2019; 94 stores less than at the time of 1999. Seven \& i Holdings has reorganized deficit wholesale marts (Ito-Yokado) to improve group profitability. Ito-Yokado already closed 20 of its 182 wholesale marts in 2017 and will close 40 cumulative stores until 2021 (leaving 142 stores) [26].

In Korea, the sales of department stores and wholesale marts in major companies have declined, and the companies plan to close deficit department stores and wholesale marts. Also, some hotels and bus terminals that cannot keep up with trend changes have deteriorated, and thus became grayfields. The logistic warehouses that were once located in outskirts are now located in surrounding housing or buildings due to the urban expansion losses their competitiveness.

Some studies assert that the grayfield retrofit has the benefits. The grayfield redevelopment as a type of infill development is now more desirable than new town and suburban development due to high infrastructure costs. Grayfields located in urban areas can satisfy variable demand by mixed-use development and regenerate a community by infusing the community activities and raising the value of real estate on the communities $[4,5,27,28]$.

However, despite its benefits, grayfield redevelopment is relatively difficult to achieve, and there are not many successful cases [5]. The constraints of grayfield retrofit are discussed by Sochar (2008) [24] and Merritt (2006) [5]. They conclude that redevelopment costs of grayfield are high in the improvement part due to low architectural value of the existing building and a lack of fiscal support from the government. The buildings of grayfields are usually windowless box-shaped buildings that may not be used for other purposes and have less value to preserve, so a reconstruction or total remodeling would be required to turn them into housings or offices [29]. Also, there are no central government mechanisms to reduce redevelopment costs because of a lack of research on the external impact of developing grayfields [5]. (On the other hand, there are diverse government programs which can provide fiscal and administrative supports for the redevelopment of brownfields because there are several studies that brownfields have historical/architectural value or the redevelopment of brownfields give positive externalities, such as reductions in crime, environmental hazards, and carbon emissions; improvements in the health of community; and an increase in the real estate value of the community [5].) In the case of the pre-negotiation system, it is necessary to change the city plan. In the case of suspended construction, there are also presale buildings, which can also be a problem for redevelopment.

\subsection{Different Objectives from Previous Studies}

The objective of this research is to verify the characteristics and retrofit constraints of grayfield in Korea, which shows differences from previous studies. First, it is the first grayfield research in Korea where the population density of the city is very high and urban decline has begun recently. Secondly, it examines various types of grayfield: not only commercial buildings, but also accommodations, transportation facilities, and public facilities. Thirdly, it combines both quantitative and qualitative research, examining the characteristics of the grayfields in Korea through various statistical analyses. Finally, it investigates the retrofit cases in Korea, the United States, and European countries as grounds for the needs for government policies for the grayfield revitalization.

\section{Analytic Frame}

\subsection{The Variables of Analysis}

This research investigates several variables for the grayfield sites: underutilization level, development level, site location, building improvement, planning regulations, and ownership. Their detailed variables are shown in Table 2. 
Table 2. Variables of analysis.

\begin{tabular}{|c|c|c|}
\hline & Variables & Descriptions \\
\hline Underutilization Level & $\begin{array}{l}\text { The condition of the grayfield } \\
\text { (Value }=1,2) \\
\text { Abandoned period (year) }\end{array}$ & $\begin{array}{c}1=\text { Unused (closed, unfinished construction) } \\
2=\text { Underused (high vacancy, scheduled to close) } \\
\text { Period of unused }\end{array}$ \\
\hline Architecture & Big-box building $($ Value $=0,1$ ) & $\begin{array}{c}0=\text { Ordinary building } \\
1=\text { Box-shaped with few windows }\end{array}$ \\
\hline Development Level & $\begin{array}{c}\text { FAR }(\%) \\
\text { Floors (floor) } \\
\text { Middle-rise building (Value }=0,1) \\
\text { BCR }(\%)\end{array}$ & $\begin{array}{c}\text { Floor Area Ratio } \\
\text { Floors of the building in the site } \\
1=\text { Middle-rise building ( } 3-9 \text { floors }) \\
0=\text { Low/high-rise buildings }(0-2 \text { floors or over } \\
9 \text { floors }) \\
\text { Building Coverage Ratio }\end{array}$ \\
\hline \multirow[t]{4}{*}{ Site Location } & $\begin{array}{c}\text { Site Area }\left(\mathrm{m}^{2}\right) \\
\text { Neighborhood population (people) }\end{array}$ & $\begin{array}{c}\text { Area of the grayfield site } \\
\text { The population of the neighborhood (dong, eup, } \\
\text { or myeon) }\end{array}$ \\
\hline & Distance to the city center (m) & $\begin{array}{l}\text { The shortest distance to city hall or province } \\
\text { office (In the case of the city of Seoul, those with } \\
\text { the shortest distance to City hall, Parliament } \\
\text { building, and Gangnam station.) }\end{array}$ \\
\hline & Distance to public Transportation (m) & $\begin{array}{l}\text { The shortest distance to the bus station, subway } \\
\text { station, or metro station }\end{array}$ \\
\hline & Distance to intercity transportation (m) & $\begin{array}{l}\text { The shortest distance to bus terminal, train } \\
\text { station, or interchange of highway }\end{array}$ \\
\hline Building Improvement & Improvement degree $($ Value $=0,1,2,3)$ & $\begin{array}{c}0=\text { No Improvements } / 1=\text { Interior Renovation } \\
2=\text { Total Remodeling } / 3=\text { Reconstruction }\end{array}$ \\
\hline \multirow{3}{*}{ Planning Regulation } & Land use Change (Value $=0,1)$ & $\begin{array}{c}0=\text { No change } \\
1=\text { Changes in land use }\end{array}$ \\
\hline & & $\begin{array}{c}1=\text { Included usage regulations (prohibited from } \\
\text { another purpose) }\end{array}$ \\
\hline & Free from regulation $($ Value $=1,2,3,4$ ) & $\begin{array}{c}2=\text { Regulations existed, but they were revised } \\
\text { (through a negotiation process) } \\
3=\text { Only density regulations } \\
4=\text { No related regulations }\end{array}$ \\
\hline Ownership Type & One-Owner $($ Value $=0,1)$ & $\begin{array}{c}0=\text { Multiowner (development by allotment sales, } \\
\text { joint ownership, divided ownership across land } \\
\text { and buildings) } \\
1=\text { One-owner (a single individual or entity } \\
\text { owner) }\end{array}$ \\
\hline
\end{tabular}

The data of variables was obtained from the Land Use Regulations Information Service [30], data of unfinished building [12,13], data of pre-negotiable site [14,15], data of old government offices [16], yearbook of retail industry [31], Statistics Korea [32], architecture offices, real estate companies, appraisal corporations, and articles of daily newspapers. Some insufficient sources were supplemented by satellite images and on-site visits by the researchers.

\subsection{Selection of Grayfields}

We examined grayfields in Korea that are 'abandoned or underutilized premises with the considerable site in the city'. In this research, 'abandoned premises' means shutdown buildings due to economic problems, such as low revenues, or unfinished buildings due to lack of construction funds. Moreover, we define underutilized premises as the buildings that have a vacancy rate of $30 \%$ or more, only one or two floors are being used, or their businesses expect closure due to low revenues. (We selected six underutilized department stores that are in the lowest $20 \%$ bracket of revenues (as of 2015) of the 71 department stores nationwide. In fact, these stores are considered to be closed informally by major companies and, in the case of wholesale marts, we selected 10 stores that the companies have closed or are planning to do so.) The grayfields are selected in cities with a population of 20,000 or 
more to exclude abandoned sites in the countryside. To exclude small blighted buildings, they are also selected in more than $1000 \mathrm{~m}^{2}$ of land or building areas (considerable sites).

To analyze the retrofit constraints, we also examine the retrofitted cases where the previous premises were abandoned, but new premises are built and have no vacancy within one year. (This is because the stable operation of commercial buildings is usually decided within one year.) We collected grayfield data by categories: commercial buildings, accommodations, transportation facilities, and public facilities. The list of grayfield was obtained from the list of unfinished buildings [12,13], list of pre-negotiable sites [14,15], list of and old government sites [16] (We select three sites out of the list which satisfies the criteria of the grayfield.), yearbook of retail industry [30], list of underground arcades from urban development corporations, documents from local governments, and articles from daily newspapers.

There are 122 sites in Korea that satisfy the definition of grayfields. However, there are 74 sites in this research that have all the variables in Table 2. Of the 74 grayfields, 18 sites are the retrofitted cases and 56 sites are still abandoned or underutilized premises. The $65 \%$ of grayfields ( 48 sites) are large-scale commercial buildings, and the grayfields are located in various facilities such as accommodation (10 sites), transportation facilities (10 sites), and public facilities (six sites) (see Table 3).

Table 3. Number of facilities of grayfields.

\begin{tabular}{ccc}
\hline Category & Facility & No. of Facilities \\
\hline & Shopping Mall & $0^{1}$ \\
& Department Store & 13 \\
Commercial Building $(n=48)$ & Wholesale Mart & 10 \\
& Retail Building ${ }^{2}$ & 17 \\
& Underground Arcade & 5 \\
& Wholesale Market & $0^{3}$ \\
Accommodation $(n=10)$ & Warehouse & 3 \\
& Hotel & 3 \\
& Resort Hotel & 2 \\
Transportation Facility $(n=10)$ & General Hospital & 5 \\
& Bus Terminal & 8 \\
& Train station & $0^{3}$ \\
& Airport & $0^{4}$ \\
& Parking Lot & 2 \\
\hline \multirow{2}{*}{ Public Facility $(n=6)$} & Public office & $3^{5}$ \\
& School & 3 \\
& Stadium & $0^{3}$ \\
\hline
\end{tabular}

\footnotetext{
1 Shopping malls like the Power Center in Korea have been recently developed, so there is no grayfield case.

2 In Korea, large-scale retail buildings are sometimes called shopping mall and department store. ${ }^{3}$ Some of them are redeveloped in Korea, but they were not abandoned. ${ }^{4}$ There are cases that have been unused or abandoned, but all of them are located in the countryside. ${ }^{5} \mathrm{~A}$ case (prison) is excluded from this study because the site area is more substantial than $100,000 \mathrm{~m}^{2}$ (a statistical outlier).
}

\subsection{Methods of Analysis}

The objective of this research is to verify the characteristics and retrofit constraints of grayfield in Korea. First, we analyze the common underutilization level, development level, and site location. Secondly, the study derives a factor from the development level and site location variables by factor analysis and distinguishes the types of grayfield in Korea by cluster analysis. Thirdly, it analyzes the building improvement and planning regulation variables to find the factor that enables grayfield retrofit by independent $t$-test. Fourthly, it investigates the development level, planning regulation, and ownership variables to find the retrofit constraints by independent $t$-test. Finally, it reviews 
the positive potential of grayfield, points out the tendency of grayfield redevelopment in Korea, and suggests the roles of central and local governments to bring out desirable revitalization of grayfield, not only for the site itself, but also its community.

\section{Characteristics and Retrofit Constraints of Grayfields}

\subsection{The Outline of Grayfields}

Grayfields are located throughout Korea except for Jeju region. Moreover, $76 \%$ of the grayfields (56 of 74 sites) are concentrated in Seoul/Incheon/Gyeonggi region (34 sites) and Busan/Daegu/Ulsan/Gyeongsang region (22 sites); $75 \%$ of the total population in Korea is concentrated in these regions [32]. Grayfields are located in small- and medium-sized cities as well as in metropolitan cities. A total of 39 sites are in metropolitan cities, while the other 35 sites are located in small- and medium-sized cities and towns (see Figure 1 and Table 4).

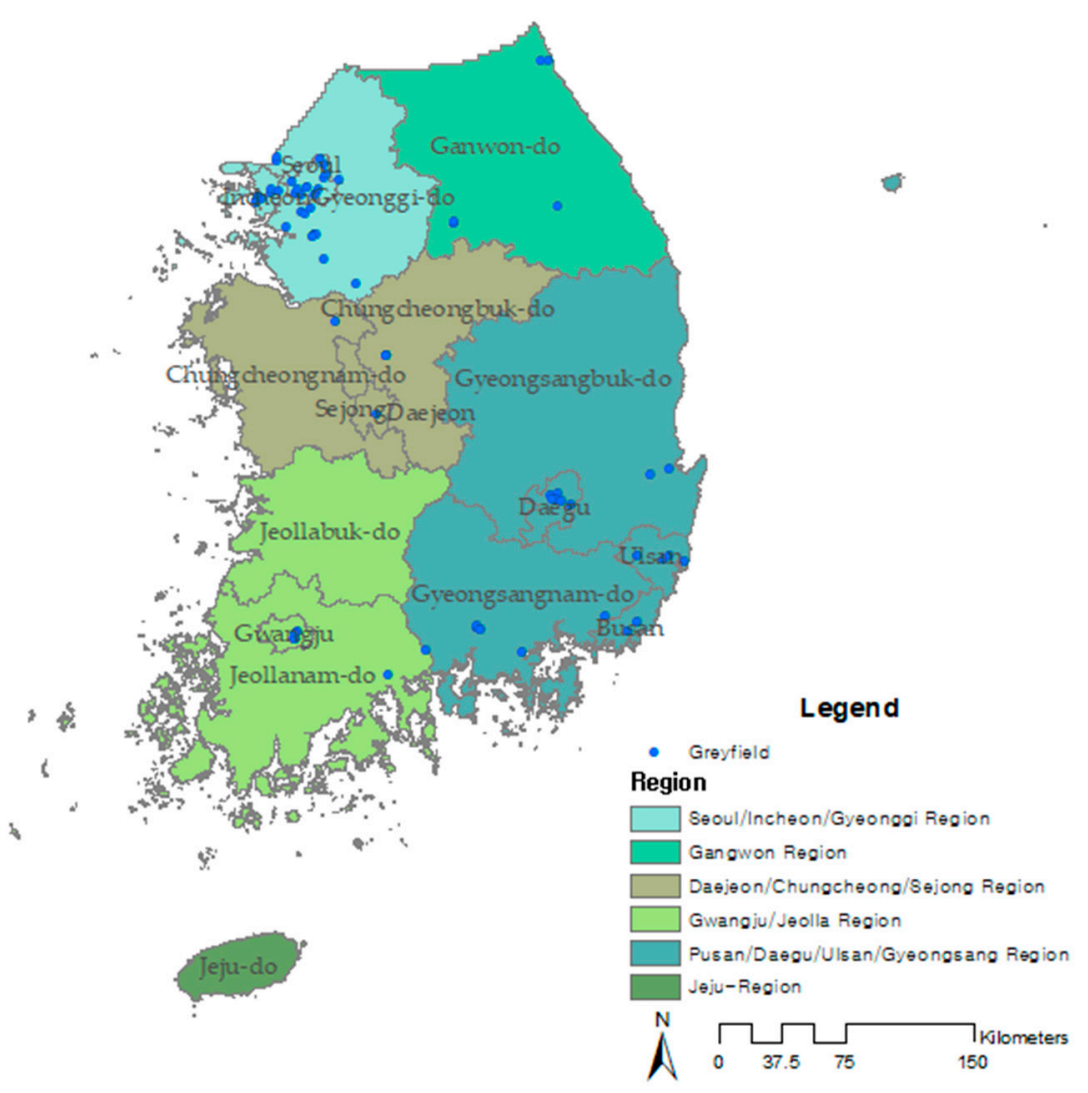

Figure 1. Location of grayfields.

Table 4. Distribution of grayfields by region and city size.

\begin{tabular}{ccc}
\hline Region & Metropolitan City & Small and Medium-Sized City \\
\hline Seoul/Incheon/Gyeonggi & 20 & 14 \\
Gangwon & $0^{1}$ & 6 \\
Daejeon/Chungcheong & 1 & 5 \\
Gwangju/Jeolla & 5 & 1 \\
Pusan/Daegu/Ulsan/Gyeongsang & 13 & 9 \\
Jeju & $0^{1}$ & 0 \\
\hline Total $(n=74)$ & 39 & 35 \\
\hline
\end{tabular}


Grayfields have been abandoned over a long period (on average of 60 abandoned buildings/sites, 10.6 years). Moreover, $66 \%$ of grayfield ( 49 sites) are big-box buildings built on a concrete slab with few windows, which need to be reconstructed or remodeled to be used as housing or offices. Grayfields in Korea have an outstanding level of accessibility through public transportation and intercity transportation. Grayfields are located at a distance of an average of $176 \mathrm{~m}$ ( $0.1 \mathrm{miles})$ from public transportation, such as bus stations and subways/metro stations, and at a distance of an average of $3.8 \mathrm{~km}$ (2.4 miles) (In the case of Transit Oriented Development, principal arterials should be located at the distance of 4.8 to $6.4 \mathrm{~km}$ (3-4 miles) from urban areas. So, grayfield can be the center of TOD area [33].) from intercity transportation, such as bus terminals, train stations, and interchanges on highways. It means that redevelopment of grayfields can both encourage transit-oriented development and respond to development demand of their neighborhoods (see Table 5).

Table 5. Common characteristics of grayfields.

\begin{tabular}{ccc}
\hline \multicolumn{1}{c}{ Characteristics } & Remarks \\
\hline Average Period Abandoned & 10.6 years & $\begin{array}{c}\text { Average of } 60 \text { abandoned } \\
\text { buildings/sites. }\end{array}$ \\
\hline $\begin{array}{c}\text { Percentage of Big-box Buildings } \\
\text { Average Distance to Public } \\
\text { Transportation }\end{array}$ & $66 \%$ & $\begin{array}{c}\text { 'Box-type' is a rectangular building } \\
\text { built on a concrete slab with few } \\
\text { windows. }\end{array}$ \\
\hline $\begin{array}{c}\text { Average Distance to Intercity } \\
\text { Transportation }\end{array}$ & $3763 \mathrm{~m}$ & $\begin{array}{c}\text { The average shortest distance from } \\
\text { bus stations, subway/metro stations. }\end{array}$ \\
\hline $\begin{array}{c}\text { The shortest distance from bus } \\
\text { terminal, train station, and } \\
\text { interchanges on highways. }\end{array}$
\end{tabular}

\subsection{Classifying the Types of Grayfields in Korea}

In order to classify the types of grayfields in Korea, this study analyzes development level (FAR, Floors, and BCR) (Among location variables, distance to public transportation and intercity transportation are excluded from the analysis because distance to public transportation of almost grayfield site (72 of 74 sites) was less than $400 \mathrm{~m}$ (1/4 miles) and distance to intercity transportation of almost grayfield site (72 of 74 sites) was less than $6.4 \mathrm{~km}$ (4 miles).) and site location (site area, neighborhood population, and distance to the city center). Avoiding multicollinearity problem among variables, Variation Inflation Factor (VIF) analysis, which quantifies the severity of multicollinearity in an ordinary least squares regression analysis and provides an index that measures how much the variance (the square of the estimate's standard deviation) of an estimated regression coefficient is increased due to collinearity [34], was performed, but there were no variables to be excluded with a VIF of 10 or more among variables (see Table 6)

Table 6. Results of tolerance and Variation Inflation Factor (VIF) among variables.

\begin{tabular}{cc}
\hline Variables & VIF \\
\hline FAR & $8.876^{*}$ \\
Floors & $7.903^{*}$ \\
BCR & $2.527^{*}$ \\
Site Area & $1.652^{*}$ \\
Neighborhood Population & $1.382^{*}$ \\
Distance to City Center & $1.387^{*}$ \\
\hline
\end{tabular}

${ }^{*} V I F<10$.

The result of the factor analysis shows that development and location variables are expressed as a single factor: 'High-density development near downtown' (see Table 7). The factor component 
values of development variables have positive values, and those of location variables have negative values. It indicates that the directions of variables are different from each other. In other words, if a site of grayfields has large development variables (high-density), then it has small location variables (relatively small site near downtown) and vice versa.

Table 7. Results of the factor analysis on development and location variables.

\begin{tabular}{cc}
\hline Variables & Factor 1 $^{\mathbf{1}}$ \\
\hline FAR & 0.869 \\
Floors & 0.791 \\
BCR & 0.708 \\
Site Area & -0.720 \\
Neighborhood Population & -0.603 \\
Distance to City Center & -0.663
\end{tabular}

${ }^{1}$ Factor extraction method: Principal component analysis. Factor Rotation Method: Varimax Rotation. (The varimax rotational approach maximizes the aggregate of required loadings variances of the factor matrix. It is fundamentally simple and appears to provide a clearer division of the factors [35]).

Therefore, the result of K-means Cluster Analysis shows that grayfields in Korea can be classified into two types: 24 low-density premises in large-scale sites with a large neighborhood in the suburb (Type I) and 50 high-density premises in mid-sized sites with a small neighborhood near downtown (Type II) (see Table 8 and Figure 2).

Table 8. Average values of developmental and location variables by clusters.

\begin{tabular}{ccc}
\hline Variables & Type I $(\boldsymbol{n = 2 4 )}$ & Type II $(\boldsymbol{n}=\mathbf{5 0})$ \\
\hline FAR (\%) & 161 & 399 \\
Floors (floors) & 3.6 & 6.9 \\
BCR (\%) & 32 & 59 \\
Site Area (m $\left.{ }^{2}\right)$ & 14,076 & 6307 \\
Neighborhood Population (people) & 31,345 & 12,467 \\
Distance to City Center (m) & 6662 & 3002 \\
\hline
\end{tabular}

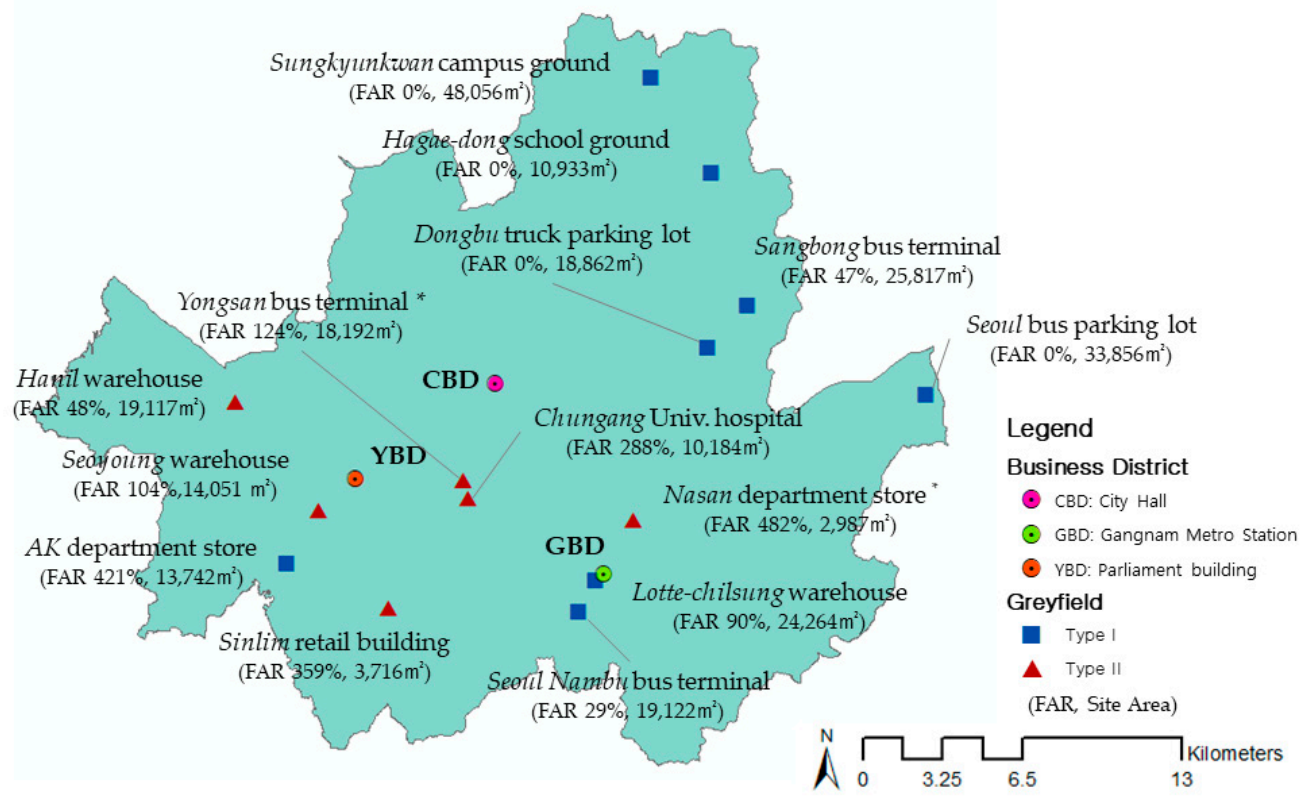

Figure 2. Location of grayfields in Seoul. * Retrofitted Site (Yongsan bus terminal $\rightarrow$ Seoul Dragon City (Hotel), Nasan department store $\rightarrow$ POBA Gangnam Tower (Office)). 
Type I is 'Grayfields on suburbs with existing low-density premises'. Type I grayfield has a low-density building or abandoned lot on large site with the populous neighborhood on suburbs located at 4-9 km (2.5-6.0 miles) from a city center. The average FAR of them is $161 \%$, the average floors of them are 3.6 stories, and the average BCR of these 24 sites is $32 \%$. Type I is located on-site with an area of approximately 1-2 ha and a neighborhood population of about 30,000 people (see Table 6). (The 95\% confidence interval of type 1 grayfield shows that accessibility to the city center is 3896-9428 $\mathrm{m}$, the site area is $8529-19,623 \mathrm{~m}^{2}$, and the population of the neighborhood is 27,170 to 35,520 people.) Moreover, the neighborhood population where Type I grayfields are located has decreased by $3.4 \%$ over the past five years, apart from the three sites that had dramatic growth recently (over $20 \%$ ). Considering development density (low building coverage ratio and low-story buildings), location (located on suburbs with a large neighborhood), and large-scale site area, Type I shows similarity to most notable grayfields; abandoned suburban shopping malls in the US, Canada, and Japan, which are located at the heart of residential suburban areas and characterized by having a large parking lot and buildings of three stories or fewer.

Type I is losing its competitiveness for their given land use. The grayfields with transportation facilities and accommodation facilities are poorly located compared to competing facilities. The grayfields with large-scale commercial buildings are small compared to competing facilities nearby. Moreover, the grayfield sites, where existing public facilities were moved to other districts or cities, were not in demand as public facilities. As a result, if Type I is not developed for other purposes, the revitalization of the site cannot take place. Figure 3 shows some examples of Type I.

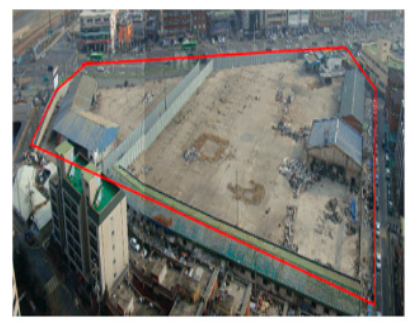

(a)

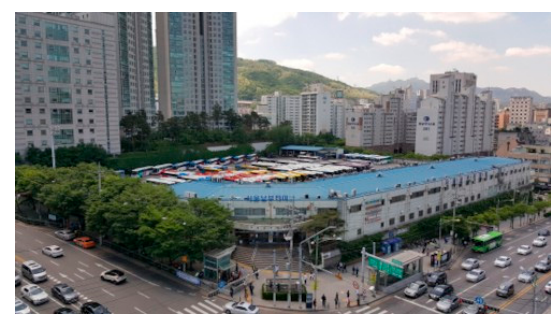

(b)

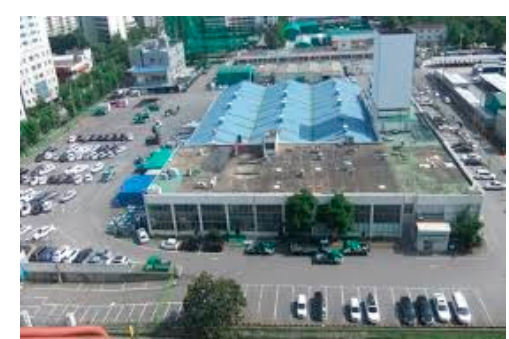

(c)

Figure 3. Examples of Type I: (a) Dongbu truck parking lot (unused), (b) Seoul Nambu bus terminal (underused), and (c) Lotte-chilsung warehouse (underused).

Type II is 'Grayfields near downtown with existing high-density premises'. Type II grayfields account for 50 of grayfields analyzed in this paper and represent a common type of grayfields found in Korean cities. They are high-density buildings or facilities in mid-sized sites with a small neighborhood (Neighborhood (dongs) in Korea that have less than 20,000 people or are smaller than $3 \mathrm{~km}$ in area are subject to merger, and administrative dongs with 10,000 people have low levels of population) near downtown located at $2-4 \mathrm{~km}(1.2-2.5$ miles) from a city center. They have a FAR of $\sim 400 \%$, buildings with around seven stories, and BCR of $\sim 60 \%$ (see Table 6 ). They are located on sites with an area of approximately $0.4-0.8$ ha and a neighborhood population of about 10,000 people. (The $95 \%$ confidence interval of type 2 grayfield shows that city center accessibility is $2119-3885 \mathrm{~m}$, the site area is $4329-8285 \mathrm{~m}^{2}$, and the population of the neighborhood is 10,616 to 14,318 people.)

Some of these grayfields (18 of 50 Type II) are located in old town, and many grayfields ( 30 of 50 Type II) are located in population-declining neighborhoods. The population of the neighborhood has decreased $2 \%$ over the past five years, apart from the two sites that had dramatic growth recently (over $100 \%$ ). Some of them (19 of 50 Type II) have been developed for sale or have split ownership of the land or buildings in contrast with overseas grayfields where a single firm owns the whole property.

Type II has a large percentage of a large-scale commercial building ( $72 \%, 36$ of 50 type II). They are, on average, eight stories high (except for five underground shopping districts), so they have less competition than new low-rise competing facilities because they do not fit the shopping path of recent 
consumers who want to see and shop much on a single floor. Type II shows some similarities to the situations of those of the suburban shopping malls in the US, Canada, and Europe, which have faced economic decline by falling behind the current shopping trends. In Korea, after the mid-1990s, large distribution companies built low-rise large department stores and wholesale marts in mid-sized cities as well as metropolitan cities. As a result, high-rise and relatively small commercial buildings have lost their competitiveness. Eventually, they had to shut down due to low revenues, or use only one or two floors of the buildings (The (former) Yeongnam Department Store operates imported bonded apparel store on parts of its first floor, while the (former) Lotte Mart Seogu Branch is operating an alternative market for nearby market merchants on its first floor. The (former) iMiz is operating an outlet on its first floor. CU and J-CITY are only operating theaters (two floors), and the rest of the buildings are empty.), or suspend the construction because their tenants did not purchase the right for buildings. The transportation facilities, accommodations, and public facilities are located close to the city center, but since there is no economic demand for this kind of land use, they have either closed or continued operation in the red. Figure 4 shows some examples of type II grayfields.

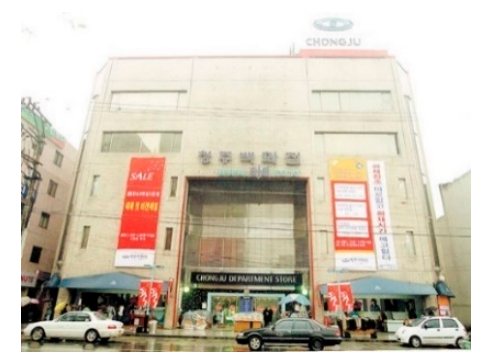

(a)

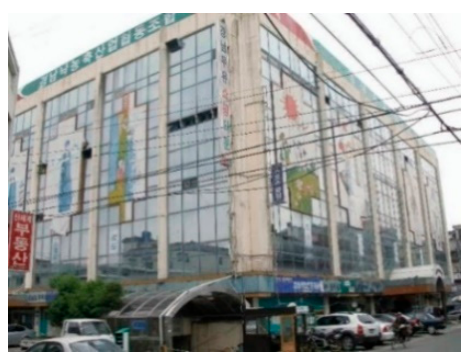

(b)

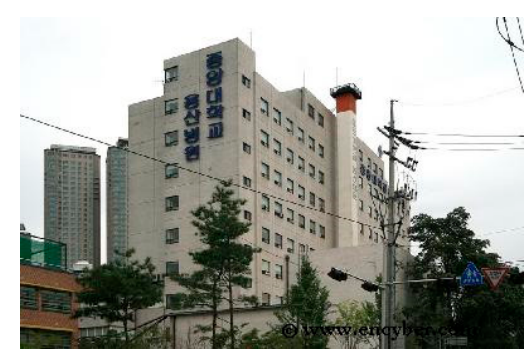

(c)

Figure 4. Examples of Type II: (a) Cheongju department store (closed, unused), (b) Yeongnam department store (closed, only one floor used), and (c) Chungang Univ. Hospital (transferred, unused).

As a result, grayfields in Korea can be divided into two types: Type I grayfields, which are characterized by low-density developments that are located on suburbs, and Type II grayfields, which are characterized by high-density development near downtown. The 74 grayfields in Korea share the common fact that they have lost their original competitiveness and have declined economically, as well as the fact that they all require revitalization through a fundamental shift in how they are used. Type I and Type II differ in their development density (FAR, Floors, and BCR) and location (site area, neighborhood population, and distance to city center), meaning that they must be revitalized by different development programs, such as the use of buildings and consumer target. Grayfields on suburbs (Type I) need a redevelopment program that satisfies housing demands and community activities. Grayfields in suburban areas of the United States and Australia are encouraged to construct the housing for families with three or more members $[4,5,18,19,27,28]$ and Mizner Park (Boca Raton, Florida, US) introduced theaters, concert halls, and art museums in new premises for its community [5]. Grayfields near downtown (Type II) also need a redevelopment program that can make the revival of a declining community by the job creation facility or residential considering job-housing accessibility. Station F (Paris, France) is the world's largest start-up campus, which is renovating a historic station. Because Facebook, L'Oreal, and Microsoft have moved into Station F, there has been a surge in real estate value in the 13th arrondissement, which was previously one of the cheapest neighborhoods to buy a home [36]. In the case of Maria 0-1 (Helsinki, Finland), the city of Helsinki renovated an abandoned hospital into a startup campus [37].

\subsection{The Activation Variables of Grayfield Retrofit}

There is a high chance that the grayfield in Korea can be retrofitted when strong improvement, such as reconstruction or total remodeling, occurs or when there is a shift in their land use. Of the 18 sites 
where revitalization had occurred among the 74 grayfields, 13 sites $(72 \%)$ underwent reconstruction, three sites underwent total remodeling, and two sites underwent interior renovation. The analysis of the relationship between improvement degree and reactivation among 74 grayfields shows that all reconstruction sites (13 out of 13 sites) and $60 \%$ of total remodeling sites (three out of five sites) were revitalized. However, only $11 \%$ of interior renovation sites (two out of 18 cases) were revitalized. All sites without improvement (38 sites) were left unused (31 sites) or underutilized (seven sites) even after the new owner bought them (nine sites). Of the 16 sites that changed their land use among the 74 grayfields, 14 sites $(88 \%)$ were successfully revitalized.

The differentiation variables between the retrofitted (18 sites) and the unretrofitted group (56 sites) were analyzed by independent $t$-test. The results of the relationship between grayfield retrofit and the improvement variations showed that the improvement degree and land use change (If the costs for demolition and construction were clearly presented in each case, it would have been possible to verify whether they are ongoing factors. However, due to the lack of data, this research instead analyzed the improvement degree through a Likert four-point scale (0 to 3).) determined the grayfield retrofit (significance probability: $p=0.000$, see Table 9). It means that the retrofit of grayfield in Korea calls for not only improvement of business management but also change in the structure and function of the premises.

Table 9. The relation between grayfield retrofit and activation variables (independent $t$-test).

\begin{tabular}{|c|c|c|c|c|}
\hline \multirow{2}{*}{$\begin{array}{c}\text { Category } \\
\text { Grayfield Retrofit }\end{array}$} & \multicolumn{2}{|c|}{ Improvement Degree $^{1}$} & \multicolumn{2}{|c|}{ Land use Change $^{2}$} \\
\hline & YES $(n=18)$ & $\mathrm{NO}(n=56)$ & YES $(n=18)$ & $\mathrm{NO}(n=56)$ \\
\hline Average & 0.78 & 0.04 & 2.61 & 0.36 \\
\hline Standard Deviation & 0.43 & 0.19 & 0.67 & 0.55 \\
\hline $\begin{array}{l}\text { Equal Variance } \\
\text { (t-statistics) }\end{array}$ & \multicolumn{2}{|c|}{0.340} & \multicolumn{2}{|c|}{$0.000^{* * *}$} \\
\hline $\begin{array}{c}\text { Average Integrity } \\
\text { (t-statistics) }\end{array}$ & \multicolumn{2}{|c|}{$0.000^{* * *, 3}$} & \multicolumn{2}{|c|}{$0.000 * * *$} \\
\hline
\end{tabular}

Therefore, the retrofit approach to the grayfields in Korea is different from that of the brownfields in Munrae-dong, Uljiro-dong, and Seongsu-dong, which have an industrial legacy and are retrofitted through partial repair or interior renovation. It is similar to the redevelopment case of overseas grayfields into apartments, condos, offices, and mixed-use developments. In the redevelopment of grayfield cases in the US and Australia, the grayfields, which are located near a populated neighborhood with TOD and MXD, are successfully developed from the perspective of the revival of local communities as well as real estate profits [2,4].

\subsection{The Constraints of Grayfield Retrofit}

The redevelopment of grayfield in Korea leads to the additional processes of demolishing and rebuilding, which means that the costs may be higher than the greenfield development and partial repair or interior renovation in the brownfield. This can be one of the factors that limit the development of grayfields. In the 32 cases of the 74 grayfields ( $43 \%)$, premises had been purchased, but only 12 sites went through reconstruction or remodeling. (Generally, local government and community expect to rebuilt the grayfield as soon as it is purchased, but typically the buyer just waits until the building collapses or the neighborhood becomes regenerated.)

To analyze the restrict variations of the grayfield retrofit, this research uses the simple economic model proposed by Merritt [5] to explain the role of construction costs and other issues in the development of grayfields that restrict their development. Generally, redevelopment will be considered if the current value of development is higher than the price of the existing assets. The present value 
of development is the same as the new site price and will also the value of the revitalized buildings minus the redevelopment costs. It can be shown in the following formula.

$$
\mathrm{L}_{\text {new }}=\mathrm{NPV}_{0}=\mathrm{V}_{0}-\mathrm{K}_{0} \geq \mathrm{L}_{\text {old }}+\mathrm{V}_{\text {old }}
$$

where $L_{n e w}$ is new site price; $N P V_{0}$ is the net present value of redevelopment; $V_{0}$ is the present value of new premises; $\mathrm{K}_{0}$ is the present value of the redevelopment costs; $\mathrm{L}_{\text {old }}$ is the costs of existing land; and $\mathrm{V}_{\mathrm{old}}$ is the costs of existing buildings.

Generally, redevelopment costs (construction and demolition costs) include the construction and demolition costs. Moreover, in Korea, there are cases in which large-scale commercial buildings (shopping malls) and accommodations (hotels and resort hotels) are developed as allotment sale, so the redevelopment costs should also include the costs of resolving ownership, such as compensation expenses to buyers. So, formula (1) can be changed as follows

$$
\mathrm{L}_{\text {new }}=\mathrm{NPV}_{0}=\mathrm{V}_{0}-\mathrm{C}_{0}-\mathrm{D}_{0}-\mathrm{O}_{0} \geq \mathrm{L}_{\mathrm{old}}+\mathrm{V}_{\text {old }}
$$

where $C_{0}$ is the present value of construction costs; $D_{0}$ is the present value of demolishing costs; and $\mathrm{O}_{0}$ is the present value of finalizing ownership costs.

However, as mentioned in Section 4.3, the development of grayfield demands land use change, so the aspect of development permission by local government, formula (2) can be shown as the following.

$$
\alpha\left(\mathrm{V}_{0}-\mathrm{K}_{0}-\mathrm{D}_{0}-\mathrm{O}_{0}\right)+(1-\alpha)\left(\mathrm{L}_{\text {old }}+\mathrm{V}_{\text {old }}\right) \geq\left(\mathrm{L}_{\text {old }}+\mathrm{V}_{\text {old }}\right)
$$

where $\alpha$ is the probability that private development plans will be permitted $(0 \leq \alpha \leq 1)$.

For an implementation for grayfield retrofitting, the adoption probability of private plans must be high, construction costs and demolition costs must be low, and finalizing ownership must be secure.

There are 24 sites out of 74 grayfields that have regulations to build for only specified uses such as bus terminals, hospital, department stores, markets, and parking lots. This means that if the central/local government does not change these regulations, they will be abandoned without the possibility of being redeveloped. So, the removal or alteration of the regulations would lead to higher chances of revitalization taking place. However, the number of sites where the regulations were revised through negotiations or supports from the local government is only seven (29\%). Despite the small number of cases, five sites are revitalized already, and two sites are in the process of development planning.

Considering the aspect of resolving ownership, it is much easier when one or only a few owners own the assets. If many tenants purchase premises through allotment sales or the building owner of the site is different from the landowner of the same site, then it will be much more time-consuming and expensive to solve the ownership problem. Grayfields with divided ownership account 21 of the 74 grayfields, and there were only three sites (14\%) that were ultimately revitalized. In all three cases, it can be shown that strong leadership is needed to resolve the ownership issue. In the first case, a meeting of shop owners was held 12 years after shopping mall was closed, and they agreed on starting the remodeling process. In the other two cases, the new owner of the land provided compensation to other owners of the existing premises after gaining possession of the right to develop the land after a legal dispute. However, it is difficult for a new owner who buys an asset of grayfield to proceed with redevelopment without central/local government support. There are a minimum of $\sim 70$ and a maximum of $\sim 490$ owners of the grayfields with divided ownership except above three cases. So, even though purchase price of the sites is $10-20 \%$ of the appraised cost, it is difficult for a new owner to move forward with redevelopment.

Under the condition that reconstruction or total remodeling of the site takes place, the revitalization of the grayfield could occur on sites where the demolition costs for buildings are small.

In terms of development size of existing premises, at the site where its existing building was built on, less than ten stories can be revitalized. The existing building on the grayfields which have 
ten floors or more remained unused due to its high demolition costs, except three sites with excellent locations in the Korean new town. (Among the three cases, one site came under a public improvement project of the abandoned buildings by the central government.)

To analyze the relationship between grayfield retrofit and its restricting variables, this study conducted an independent $t$-test on the variables between retrofitted and unretrofitted group: Free from Regulations (the probability that a private development plan will be permitted), One-owner (the costs to finalize ownership), Floor Area of Building, and Middle-rise Development. (Middle-rise development means that its floors of building are three to nine. High-rise building has 10 stories or more, low-rise building has two stories or less. Low-rise buildings are restricted due to regulations) (demolition costs.) This analysis founds that there are significantly different in Free from Regulations ( $p=0.028)$, Middle-rise Development $(p=0.030)$, and One-owner $(p=0.083)$ between the retrofitted and unretrofitted group. However, Floor Area of Building is not statistically significant even at the $90 \%$ confidence level $(p=0.101)$ (see Table 10).

Table 10. The relation between grayfield retrofit and constraints (independent $t$-test).

\begin{tabular}{|c|c|c|c|c|c|c|c|c|}
\hline \multirow{2}{*}{$\begin{array}{c}\text { Category } \\
\text { Grayfield } \\
\text { Retrofit }\end{array}$} & \multicolumn{2}{|c|}{$\begin{array}{c}\text { Free from } \\
\text { Regulations } 1\end{array}$} & \multicolumn{2}{|c|}{ One-Owner $^{2}$} & \multicolumn{2}{|c|}{$\begin{array}{c}\text { Floor Area of } \\
\text { Building }\end{array}$} & \multicolumn{2}{|c|}{$\begin{array}{c}\text { Middle-Rise } \\
\text { Development }^{3}\end{array}$} \\
\hline & $\begin{array}{c}\text { YES } \\
(n=18)\end{array}$ & $\begin{array}{c}\mathrm{NO} \\
(n=56)\end{array}$ & $\begin{array}{c}\text { YES } \\
(n=18)\end{array}$ & $\begin{array}{c}\mathrm{NO} \\
(n=56)\end{array}$ & $\begin{array}{c}\text { YES } \\
(n=18)\end{array}$ & $\begin{array}{c}\mathrm{NO} \\
(n=56)\end{array}$ & $\begin{array}{c}\text { YES } \\
(n=18)\end{array}$ & $\begin{array}{c}\mathrm{NO} \\
(n=56)\end{array}$ \\
\hline Average & 3.44 & 2.73 & 0.89 & 0.68 & 23,721 & 15,994 & 0.72 & 0.43 \\
\hline $\begin{array}{l}\text { Standard } \\
\text { Deviation }\end{array}$ & 1.30 & 0.62 & 0.32 & 0.47 & 17,531 & 13,939 & 0.46 & 0.50 \\
\hline $\begin{array}{c}\text { Equal } \\
\text { Variance } \\
\text { (t-statistics) }\end{array}$ & \multicolumn{2}{|c|}{$0.000^{* * *}$} & \multicolumn{2}{|c|}{$0.000^{* * *}$} & \multicolumn{2}{|c|}{0.133} & \multicolumn{2}{|c|}{$0.007^{* * *}$} \\
\hline $\begin{array}{l}\text { Average } \\
\text { Integrity } \\
\text { (t-statistics) }\end{array}$ & \multicolumn{2}{|c|}{$0.028^{* *}$} & \multicolumn{2}{|c|}{0.083 * } & \multicolumn{2}{|c|}{$0.101^{4}$} & \multicolumn{2}{|c|}{$0.030 * *$} \\
\hline
\end{tabular}

${ }^{1}$ No related regulations $=4$, Regulations existed, but they were revised (through a negotiation process) $=3$, Only density regulations $=2$, Included usage regulations (prohibited from any other purpose) $=1 .{ }^{2}$ One-owner (a single individual or entity owner) $=1$, Multiowner (development by allotment sales, joint ownership, divided ownership across land and buildings) $=0 .{ }^{3}$ Middle-rise building (3-9 floors) $=1$, Low/high-rise buildings (buildings lower than two stories or higher than nine stories, including sites and underground facilities) $=0 .{ }^{4}$ Significant probability was the value when equivalence was not assumed. ${ }^{* * *} p<0.01,{ }^{* *} p<0.05,{ }^{*} p<0.10$.

Ten of 18 retrofitted grayfields are sites without constraints: these sites are owned by one private company, the floors of existing buildings are three to nine, and there is no related regulation or regulations are revised on site). As a result, when developing grayfield, it is desirable for the private sector to purchase the site with middle-rise building and without usage regulations, and ownership problems and the central/local government should support changing urban planning regulations, resolve ownership problems, and reduce building demolition costs before redeveloping grayfields. Figure 5 shows grayfield retrofit cases.

The Urban Land Institute introduced the three-step process to deal with empty premises [29]. The first phase involves deciding on the new use of the site after its design and engineering considerations are completed, the second phase requires a cost analysis to determine whether the reuse of the site is economical or not, and the third phase requires gap financing from local governments if needed. In other words, the use of sites must be changed into one that differs from the current use and is appropriate for the site and local revitalization. Economic development methods (reconstruction or remodeling) must be determined. Moreover, government support must be obtained to resolve issues of ownership and demolition costs, along with the lifting of regulations that will allow the development to take place. 


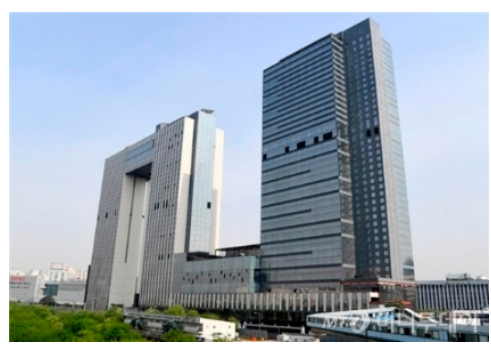

(a)

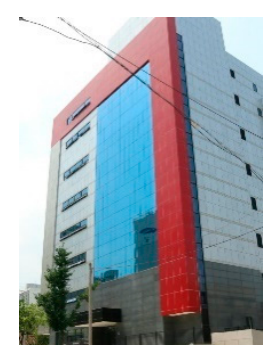

(b)

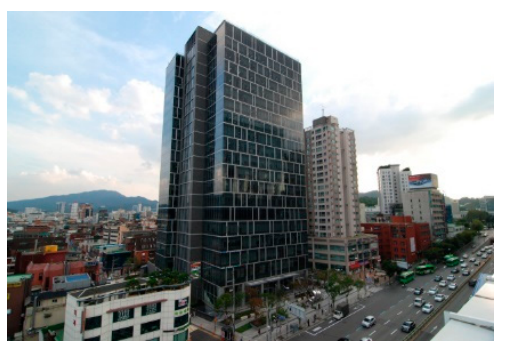

(c)

Figure 5. Grayfield Retrofit Case: (a) Seoul Dragon City (Regulation revised; Reconstruction; Bus Terminal $\rightarrow$ Hotel), (b) Doyoung Tower (Meeting of shop owners was held; Total Remodeling; Shopping mall $\rightarrow$ Shopping and Office Building), (c) POBA Gangnam Tower (Middle-rise Building; Reconstruction; Department store $\rightarrow$ Office).

\subsection{The Positive Effects of Grayfield Retrofit and Role of the Government}

The redevelopment of grayfield in Korea has three positive effects on the community. Firstly, the redevelopment of grayfield in Korea can solve social, economic, and landscape issues of the neighborhood. The economically declined or abandoned premises can damage a landscape of the neighborhood and also be used as sites for the crime. Especially, if a grayfield is located in a commercial district in the small or medium-sized city, it will also bring the decline of the whole district. Out of the 16 sites on the commercial district in small or medium-sized cities, the whole marketing area of 11 sites is economically deteriorated after the sites are abandoned. Also, a grayfield located in the suburbs fails to fit in with the land use of surrounding areas and prevents the development of the community. There are complaints to demolish and reconstruct grayfields by residents who live near the grayfields (69 of 74 grayfields). Since the premises that have made problems in the past will disappear by reconstructing or remodeling, the redevelopment of grayfields can solve social, economic, and landscape problems.

Secondly, the development of grayfield in Korea can be a way to regenerate its community. Generally, the decline of the area in the city occurs when middle-class residents move out to other areas. As mentioned in Section 4.2 and above, the grayfields in Korea are located in areas in decline, such as population-declining neighborhoods or defunct commercial districts. If middle-class residents return to live or work on the retrofitted grayfield in the deteriorated neighborhood, the grayfield can save and revitalize the neighborhood from decline. Grayfields in Korea comprise a large development site that can serve as community centers because the average area of Type I sites is $\sim 1.4$ ha and the average area of Type II sites is $0.6 \mathrm{ha}$. Also, the size of development can accommodate various functions that can entice the middle-class as well as neighborhood residences to establish a foothold for the revival of the neighborhood. (Local governments can benefit from receiving tax revenues by increasing the real estate value of the neighborhood.) The previous redevelopment projects for the old town have chased out residents in the process of the demolition of the whole community. However, the retrofit of grayfields which is developed on an abandoned single site can be a solution for regeneration without damage to the community.

Thirdly, grayfields in Korea are good target sites for infill and transit-oriented development that can bring about reductions of carbon emissions. Grayfield development has the potential to bring about a reduction in environmental pollution and carbon emissions compared to greenfield development $[5,27,28]$. The edges of cities have been expanding due to the greenfield development, leading to a burden on infrastructure and a split between residential and commercial area. Most of the grayfields in Korea (71 sites) are located within $16 \mathrm{~km}$ (10 miles) from the city center, and 60 sites are located within $8 \mathrm{~km}$ (5 miles) from city center surrounding other buildings, so that grayfields can be the site for infill development. Also, grayfield can be a good TOD site without additional transportation infrastructure. Distance to public transportation of most grayfields (72 sites) was less than $400 \mathrm{~m}$ (1/4 miles), which means it is a walkable distance and distance to intercity transportation of most 
grayfields (72 of 74 sites) was less than $6.4 \mathrm{~km}$ (4 miles)—the distance between the urban area and principal arterials. Therefore, redeveloping grayfield instead of greenfield will reduce carbon emission because of lower vehicle traffic and reduction of environmental destruction (The development of one acre of brownfield saves 4.5 acres of greenfield and reduces carbon emissions because of the lower vehicle traffic [5]).

Despite the three potentials, the redevelopments of grayfield in Korea have been simple real estate developments to maximize profit and failed to regenerate communities. Out of 18 retrofitted grayfield, 11 sites were developed for apartment complexes and high-rise residential building (officetel), but the developers of them did not contribute to the nearby communities by accommodating or operating public facilities after selling residential buildings. Even 2 cases out of 11 residential redevelopment projects are public improvement project by the central government and public developer (LH) (LH (Korea land housing corporation) is a government-owned corporation that is responsible for the development of land and housing in cities, especially new towns). This type of development is similar to the development of brownfields in Korea in the past. Since the 1990s, expansion of cities and capital area regulation on the Seoul Metropolitan Area (SMA) has led to the move of big-size factories located in SMA to areas outside of the SMA [38]. This led to the redevelopment of brownfields in Seoul and other cities of SMA [38]. However, most cases of brownfield redevelopment are only for apartment complexes except for only a few mixed-use developments [38]. Developers, like the redevelopment of grayfields, built new premises in brownfields and sold all assets to new residences. So, there are no operating entities associated with developers who share development profits, and there are few positive effects on communities. Therefore, if the government does not improve its policy on supporting the developers and public contribution, grayfield redevelopment will not generate enough of a positive effect on its community.

In order to not only revitalize grayfields but also regenerate their communities, the government should take charge of two policies. Firstly, the central government should make a comprehensive incentive policy for the grayfield to establish relevant laws and secure fiscal resources, and local government should establish a grayfield agency to support revision of planning regulation, financing to demolish existing premises and rebuild community facility, arbitration for resolving divided ownership, as well as urban planning advisory.

For now, the local and central governments provide only partial support for similar projects. The city of Seoul operates the Pre-Negotiation System to change urban planning to factories, warehouse, bus terminal, train station, wholesale market, and public facilities $[14,15]$. The central government purchased a few abandoned private or local government assets to reconstruct as a pilot project. However, there is no arbitration or legal support for developers, and many local governments are suffering from a lack of comprehensive incentives. In particular, public officials are usually afraid of attempting to change regulations or provide fiscal support to encourage the redevelopment process because they may be seen as giving special favors. Therefore, if the central government does not make a comprehensive incentive policy and the local government does not establish a grayfield agency in charge of the comprehensive incentives, most of the public officials consequently will adopt a passive stance towards support for grayfield redevelopment.

In the case of Mizner Park (Boca Raton, FL, USA), the city of Boca Raton established a CRA (Community Redevelopment Agency) and provided \$50 million in support for improvements to the local infrastructure. The CRA introduced Tax-Increment Financing (TIF) (This was a case where the government took the first step to invest after considering future tax revenue increases through tax-increment financing.) to encourage cultural centers to invest $\$ 68$ million. In the case of Metropolitan Midtown (Charlotte, NC, USA), Charlotte and Mecklenburg counties constructed a $\$ 60$ million adjacent road and greenway, and supported \$17 million TIF allowing parking lots to be developed into high-density residential buildings [5].

In addition to fiscal support for demolishment or construction, there are ways for the government to support the initial operation and development planning. Local government may move public offices 
to the new premises or support some of the leasing fees for start-up companies or social enterprises. The city of Gwangju (South Korea) purchased an abandoned department store and use it as a district office (Nam-gu office) and retail building (But the leasing fee of the retail building is so expensive for shop owners that the retail building is still vacant. Because the rent of buildings operated by the public entity is based on appraisal prices, the public entity cannot be allowed to set rents below the appraisal prices) [39]. In the case of Bullring Center (Birmingham, UK), the city council commissioned a survey to assess retail accommodations in the site [40].

Many local governments in Korea prefer to redevelop the grayfields into high-density buildings regardless of real estate demand. However, it is desirable for the local government to encourage development planning and program that remove the poor reputation of the areas rather than merely inducing high-rise development, which raises development and operational costs. In the case of new Downtown Kendall (Kendall, FL, USA), the city of Kendall tried to turn potential customers' attention by giving master-plan to renowned new urbanism planning company [5]. In the case of Tysons (Fairfax, VA, USA), the new urbanist Andres Duany was asked to design the site to get rid of its reputation as a place congested by traffic, and was subsequently developed [5].

Secondly, the local government should demand a new public contribution to regenerate the community by the private developer. In order to achieve an appropriate density of development and long-term stable operation, it is desirable that the developer operates the site after the redevelopment, rather than liquidate it. Therefore, local governments should review the long-term operation abilities of the developers, rather than development plans only, and provide incentives to developers that meet these criteria by negotiations. In the case of an overseas retrofit, the developers are the operators of the premises, so they earn the profits from long-term rental income.

In the past, the public contributions have focused on the public contribution of only road or park. Recently, local governments are demanding the introduction of various facilities [15]. (In the case of the Pre-Negotiation System, the contributed acceptance of following facilities was discussed; rental housings, pedestrian roads, cultural/welfare facilities, accommodations [11].) However, public contribution as a demand for the incentives should include not only building and donating, but also operating the community facilities such as art center, museum, library, parking lot, community center, and office park. In the case of Mizner Park (Boca Raton, FL, USA), museums, libraries, and community centers are located on the premises and are operated by the developer [5]. Also, in the case of Bullring Center (Birmingham, UK), the developer (Birmingham Alliance, UK) contributed by rebuilding the two indoor markets nearby and managing them for three years after the new premises opened [40].

\section{Conclusions}

Recently, the decline of old urban areas and the destruction of commercial districts in small and mid-sized cities in Korea have become a problem. Also, there has been stagnation due to the lack of foothold for revitalization in some areas on suburbs. In this situation, grayfield, an abandoned noncommercial premise, could be a good site for the neighborhood and urban regeneration. Therefore, we focused on the grayfields with which previous researches in Korea have not dealt with systematically.

The study shows that there are two types of grayfields in Korea by location and density; the first type is 'Grayfields on suburbs with existing low-density premises' and the second is 'Grayfields near downtown with existing high-density premises'. It is necessary to consider the retrofit method depending on their location and density. Grayfields near suburbs need a redevelopment program that satisfies housing demands and supports community activities. Grayfields near downtown also need a redevelopment program that can make the revival of a declining community by establishing job creation facilities or housing considering job-housing accessibility.

It shows that grayfields in Korea can be revitalized by steady improvement and the change of land use. Therefore, if a developer renovates only a part of a building and uses for existing purposes after purchasing the site, it will be challenging to guarantee revitalization of it. In Korea, there are only a few retrofit cases for grayfields. The results of the analysis show that the restriction factors of 
grayfield redevelopment are strict urban planning regulation, divided ownership, and demolition costs of existing high-rise premises. Consequently, the redevelopment of grayfields cannot be achieved without government supports.

The redevelopment of grayfields in Korea has positive effects on the community, which include not only preventing social and economic decline of its community, but also the regeneration of its community and increasing the sustainability of the city by reducing carbon emissions. However, because the present government's role has been weak, the grayfields in Korea have either been abandoned or developed without contribution to their communities. Therefore, the central government must make a comprehensive incentive policy, and the local government must establish a grayfield agency to encourage redevelopment and contribution to the community. Also, it will need to encourage private developers to operate the new premises. In other words, regulations should be relaxed, but private developers should be able to contribute to the community by operating the new premises for a longer period.

This study is significant for showing the characteristics of grayfields in Korea and analyzing their redevelopment factors through both qualitative and quantitative analysis. However, it did not deal with externality of grayfield redevelopment, and there was a lack of case studies about the redevelopment grayfields in European and Asian countries. These limitations will be compensated for in future research.

Author Contributions: Conceptualization, J.-W.S.; Literature Review, J.-W.S.; Methodology, J.-W.S. and J.-L.L.; Validation, J.-L.L.; Formal analysis, J.-W.S.; Investigation, J.-W.S.; Resources, J.-W.S.; Data curation, J.-W.S. and J.-L.L.; Writing—Original Draft Preparation, J.-W.S.; Writing—Review and Editing, J.-W.S. and J.-L.L.; Supervision, J.-W.S.

Funding: This research received no external funding.

Acknowledgments: We would like to thank Ji-Weon Jung for revising the use of English.

Conflicts of Interest: The authors declare no conflicts of interest.

\section{References}

1. Congress for New Urbanism, Price Waterhouse Coopers. Greyfields into Goldfields: From Failing Shopping Centers to Great Neighborhoods; Congress for New Urbanism: San Francisco, CA, USA, 2001.

2. Kichline, M.; Cozzone, K.; Farrel, T. Commercial Landscape Series: Transforming Greyfields into Dynamic Destinations; Chester County Planning Commission: Westtown, PA, USA, 2017.

3. Sobel, L.S.; Bodzin, S.; Greenberg, E.; Miller, J. Greyfields into Goldfields: Dead Malls Become Living Neighborhoods; Congress for the New Urbanism: San Francisco, CA, USA, 2002; ISBN 0971884110.

4. Bucher, D.C. Case study: Greyfields as an emerging smart growth opportunity with the potential for added synergies through a unique mix of uses. Real Estate Issues 2002, 27, 46-54.

5. Merritt, A.W. Redeveloping Greyfields: Definition, Opportunities, and Barriers. Master's Thesis, Science in Real Estate Development, Massachusetts Institute of Technology, Boston, MA, USA, June 2006.

6. Hadjimichael, G. From Brownfields and Greenfields to Multi-Fields; Science Journal of Riga Technical University: Riga, Latvia, 2011; pp. 37-45.

7. Land Economy and Construction Industries Bureau (in Ministry of Land, Infrastructure), Transport and Tourism. Guide on Improvement of Area Value by Regenerating Idle Asset; Ministry of Land, Infrastructure, Transport and Tourism: Tokyo, Japan, 2015.

8. Kang, D. Urban Regeneration Methodology through Reuse of Industrial Heritage: Focused on Comparison of Industrial Typology. J. Urban Des. Inst. Korea 2010, 11, 157-178.

9. Lee, J. The Case Study of the Brownfield Development for Modeling of Korea. Geogr. J. Korea 2016, 50, $425-437$.

10. Jo, Y.; Lee, H.; Kim, D. Reutilization of Negatively Perceived and Neglected Urban Resources. J. Urban Des. Inst. Korea 2015, 16, 161-172.

11. Park, S.; Kim, S.; Yoon, J. Policy Suggestions for Regeneration and Reuse of Empty Homes in Deprived Areas; Architecture and Urban Research Institute: Sejong, Korea, 2016. 
12. Kim, J.; Yoon, J.; Ryu, D.; Oh, H. Rehabilitation Plan Considering the Condition of Unfinished Buildings; Land and Housing Institute: Daejeon, Korea, 2018.

13. Yu, K.; Lim, Y. Addressing Abandoned and Unfinished Buildings Management: An Institutional Framework; Architecture and Urban Research Institute: Sejong, Korea, 2013.

14. Evaluation Team of Pre-Negotiation System for Urban Planning Change. Report of Evaluation of Pre-Negotiation System for Urban Planning Change; Seoul Metropolitan Government: Seoul, Korea, 2009.

15. Joo, M.; Lee, S.; Lee, J. Improvements and Operational Features of Pre-Negotiation System for Urban Planning Change. J. Urban Des. Inst. Korea 2017, 18, 23-38.

16. Ministry of Economy and Finance. Implementation Plan to the Leading Project for the Redevelopment of Old Government Office; Ministry of Economy and Finance: Sejong, Korea, 2015.

17. Kalinosky, L. Balancing Acts: The Experience of Mutual Housing Associations and Community Land Trusts in Urban Neighborhoods; Community Service Society of New York: New York, NY, USA, 1996; ISBN 0881561738.

18. Chilton, K. Greyfields: The New Horizon for Infill and Higher Density Regeneration; Center for Environmental Policy and Management in University of Louisville: Louisville, KY, USA, 2004.

19. Homsy, G. New Lives for Old Malls: Rethinking the Nation's First Generation of Shopping Centers. Planning $1999,65,20-22$.

20. Number of Retail Store Openings and Closures in the United States in 2017. Available online: https: //www.statista.com/statistics/757160/retail-store-opening-closing/ (accessed on 10 April 2018).

21. Net Sales Revenue of Amazon from 2004 to 2018 (in Billion U.S. Dollars). Available online: https: //www.statista.com/statistics/266282/annual-net-revenue-of-amazoncom/ (accessed on 10 April 2018).

22. Sears Number of Stores in the United States from 2011 to 2017. Available online: https://www.statista.com/ statistics/293036/number-of-sears-stores-united-states/ (accessed on 10 April 2018).

23. Why Macy's Is Closing More Stores in 2019. Available online: https://finance.yahoo.com/news/why-macyapos-closing-more-023400887.html (accessed on 2 January 2019).

24. Number of Shopping Centers in Japan. Available online: http://www.jcsc.or.jp/sc_data/data/overview (accessed on 29 March 2019).

25. Japan Department Store Association. Department Store Sales Overview Nationwide; Japan Department Store Association: Tokyo, Japan, 2019.

26. Seven \& I Holdings. Seven E I Holdings Co., Ltd. Growth Strategy; Seven \& I Holdings: Tokyo, Japan, 2016.

27. Newton, P.W. Beyond greenfields and brownfields: The challenge of regenerating Australia's greyfield suburbs. Built Environ. 2010, 36, 81-104. [CrossRef]

28. Australian Housing and Urban Research Institute. Processes for Developing Affordable and Sustainable Medium-Density Housing Models for Greyfield Precincts; Australian Housing and Urban Research Institute: Melbourne, Australia, 2015.

29. Sochar, B.H. Shining the light on greyfields: A Wal-Mart case study on preventing abandonment of big-box stories through land use regulations. Albany Law Rev. 2008, 71, 697-730.

30. Korea Chain Store Association. The Year Book of Retail Industry 2010-2015; Korea Chain Store Association: Seoul, Korea, 2015.

31. Land Use Regulations Information Service. Available online: http://luris.molit.go.kr (accessed on 18 November 2018).

32. Population by Administrative District (Province, City). Available online: http://kosis.kr (accessed on 24 March 2019).

33. Steiner, F.R.; Butler, K. Planning and Urban Design Standards; John Wiley \& Sons, Inc.: Hoboken, NJ, USA, 2007.

34. Variation Inflation Factor. Available online: https://en.wikipedia.org/wiki/Variance_inflation_factor (accessed on 26 March 2019).

35. Hair, J.F.; Black, W.C.; Babin, B.J.; Anderson, R.E.; Anderson, R.E. Multivariate Data Analysis: A Global Perspective, 7th ed.; Pearson-Hall International: Upper Saddle River, NJ, USA, 2010.

36. How Station F Transformed Paris into the Start-up Capital of France. Available online: https://www. architecturaldigest.com/story/how-station-f-transformed-paris-into-start-up-capital-france (accessed on 27 March 2019).

37. Maria 0-1: Helsinki is Turning an Abandoned Hospital into a Massive Startup Campus. Available online: https://venturebeat.com/2016/12/25/maria-0-1-helsinki-is-turning-an-abandoned-hospital-into-amassive-startup-campus/ (accessed on 27 March 2019). 
38. Kim, J.; Sohn, D.; Chin, L. Limitation of Land Use Controls to Manage a Manufacturing Zone; A Case Study of the Yeongdungpo Manufacturing Area in Seoul. J. Urban Des. Inst. Korea 2014, 15, 107-120.

39. Choi, J.; Kim, H.; Shin, W. A study on actual conditions and improvement methods in non-residential large-scaled abandoned buildings-Focused on the cases in Namgu, Gwangju. Stud. Reg. Dev. 2015, 47, 133-147.

40. Kramer, M. ULI Development Case Study: Bullring Center; ULI-the Urban Land Institute: Washington, DC, USA, 2008.

(C)

(C) 2019 by the authors. Licensee MDPI, Basel, Switzerland. This article is an open access article distributed under the terms and conditions of the Creative Commons Attribution (CC BY) license (http://creativecommons.org/licenses/by/4.0/). 